PROSE

\title{
A Burger with the Lot Robert Campbell
}

"FuCK THAT NOISE. If it's not forty-five degrees out there, I'll bare me arse in Bourke Street." Spat the red-faced old bastard cemented to the end of the bar.

You had to be careful saying that out loud. It had become so much of a problem that the government had to take action and you could now be charged with the very serious crime of Conspiracy to bare ones arse on Bourke Street. It counted for other streets, but they carried fewer penalties.

He was right though. The Court Jester was a very old pub, and it was built in such a way that no matter how hot it was outside, it was always relatively comfortable to sit inside. The cold beer definitely helped too. Opening the solid wooden door instantly reminded you of exactly how brutal the weather was outside.

"The Dreg's got nothing this place don't have. I'm staying right here, until that sun goes down. Maybe even a few hours after. I swear it never got below forty last night," he continued.

That was right, too. In fact, the entire week had maintained a fairly constant forty degree heat. Not a damn cloud in the sky either, just pure belting sunlight, all damn week. For John; a short, stocky man in his forties and past the peak of his physical fitness, the factory had been hell. His heavy cotton work shirt had been sticking to his skin all day and he could barely see through the condensation that gathered on his glasses.

"Sit down, John! And close the friggen door!" 
"My dog's down at the Dreg though, and my damn pay packet." John finally said.

There was no way the boss was hanging around a factory in the heat. He was conducting all his business from his new base at The Dredgers Arms, colloquially known as 'The Dreg'. This meant he was sitting at the bar on a big envelope full of money with John's name on it.

"Surely that can wait till tomorrow. Grab another beer," the old man said, gesturing towards the bar staff with his now empty pint.

John looked at his wallet. He definitely wanted another beer; even just standing here with the door open was taxing in this heat. However, all it contained was a ten dollar note and maybe a bit of change, a buck fifty at the most.

"No, won't make it till dinner on this," he said. "Besides, like I said, my dog's down there."

"Good luck to you, mate. Guarantee, there's not a thing open between here and there."

"I'll have to take my chances. See you next week mate?"

"I'll be here Johnny."

Of course he would, they all would, old pricks that they were. John wasn't the biggest fan of The Court Jester, or anyone in it. But at least this old prick - John had long forgotten his name - was tolerable as long as you steered the conversation away from immigrants, politics, women or the news. Football seemed to be a safe bet, as long as you kept clear of mentioning any of 'the blacks' or 'the wogs'. Actually, it was probably best not to mention football either. Either way, he was tolerable enough to talk to for as long as it took to drink the one or two beers John usually had on his way home. He came to The Court Jester for geographical convenience more than anything else. It was a good distance from both work and his house, but if he really wanted a drink he'd head to The Dreg. The Dreg was his home.

John shook the old prick's hand and tried hard to remember his name. It might have been Charlie or Jack, or something like that, but that was just a nickname. His real name was Barry or Harry, or something, and for whatever stupid reason he was nicknamed Charlie or Jack, or something. It was ridiculous in any case, but John couldn't quite put his finger on it so he went with the safe bet of 'Chief'.

"Righto Chief, look after yourself."

"You too Johnny, say hi to the missus." Chief replied, loosening his sweaty grip. 


\section{Robert Campbell}

John chose not to acknowledge that, he doubted the missus would like to hear that the old racist prick from down the pub said "hi". He walked towards the massive wooden door again and pushed it open. The sun, although low in the sky, was relentless and the bitumen radiated with the heat it had absorbed throughout the long day. All the old pricks moaned and groaned and cursed until John was outside with the door swinging shut behind him. He started to wonder whether his pay check could wait until tomorrow, but in any case, he would still have to go and get the dog. The direction the street was facing meant that there was next to no shade for a good portion of his walk. John could barely see the shops a few hundred metres away through the wavy distortion given off by the road. He figured that the walk couldn't be any worse than the week he had spent sweltering away in that factory, but after the first few steps he began to change his mind. The heat was a bitch.

The burger shop seemed to appear almost miraculously at the exact half way point between The Court Jester and The Dreg. The cooling affects of the last pint had long worn off and the few drinks John had already downed had left him hungry. He had never been to this burger shop before, despite taking this same path almost every Friday for as long as he could remember. It was an old building, a dilapidated antique among the newly renovated shopfronts. While the original business name had been covered up, the words Est. 1898 could still be seen below it. The sign read Hank's Cold Drinks E Premium Eats, its condition however, suggested that the drinks would not be cold and the eats would be far from premium. A quick survey of the quiet street around him and John soon realised that he had no other choice. Most of the locals had been driven to one of the pubs, including most of the business owners. Hank's was the only exception.

The colourful plastic strips over the door offered no protection from the heat or the flies. A tiny metal fan, a rusty pre-war relic, hummed on the counter to no avail. Above it, a neon blue bug zapper cracked with every little fly that entered its field, all the while letting out a low buzz that suggested there may have been some dodgy wiring and was seconds away from going up in flames. The old man at the counter, presumably named Hank, seemed unfazed by this as he leaned on the bench top with a poorly rolled cigarette in his mouth. John got the impression that he was unfazed by most things, judging by the mixture 
of sweat and chip oil that had collected on his face. Over in the corner sat a fridge, a busted old piece of shit, stained a dirty yellow and missing the freezer door. But John could see that it was plugged in, meaning that whatever was inside - hopefully some drinks, but more than likely out of date burger meat - would be cold. With a little bit of luck there may even be a beer, but John tried hard not to get his hopes up.

"Howyagoin', boss?" he asked, forcing a smile.

The old man said nothing, as several flies landed on his face. John gestured with his hand to alert the old man to this fact, but again he did nothing. John was beginning to wonder if going thirsty was going to be a better option, but he had come too far. Next to the dodgy bug zapper was a chalkboard, and on it a simple and poorly written menu.

Plain $\$ 4$

Chees $\$ 4.50$

Lot $\$ 5$

Chip $\$ 2$

Drink $\$ 1.50$

All chip come with choice of 1 Sauce for 20c each per each serve of chips.

Max 4 serves per person each serve of chips.

Rather than try to decipher what sort of point those last two lines were trying to get across, John decided to try his luck with a burger, although the fact that the word 'Cheese' was spelled incorrectly didn't fill him with confidence.

"What comes on the burger with the lot?" He asked, immediately regretting it. The old man's demeanour changed entirely. He stared through John with his tired eyes, a dead, cold stare that seemed to last entire minutes. It was a stare that John had seen before, the long stare of a man who had been broken, a man who was disenchanted with his situation, his life, his job, a man who felt he would never truly be happy again. John knew what was to come, so he braced himself for the worst.

The man, with flies massing around his dry cracked lips, his forehead shimmering in the dull blue glow of the bug zapper, his eyes filling with the smoke of his cigarette, leaned in and whispered ...

"Everything...." 